\title{
Comparative study of adolescents with and without ADHD
}

\author{
Macarena Pi Davanzo,' Marcela Larraguibel Quiroz,' Rodrigo Rojas-Andrade, ${ }^{2}$ Consuelo Aldunate ${ }^{3}$
}

\footnotetext{
Clínica Psiquiátrica Universitaria, Facultad de Medicina, Universidad de Chile, Santiago, Chile.

2 Escuela de Psicología, Facultad de Ciencias Sociales, Universidad Academia de Humanismo Cristiano, Santiago, Chile.

3 Departamento de Neurociencias, Facultad de Medicina, Universidad de Chile, Santiago, Chile.
}

\section{Correspondence:}

Macarena Pi Davanzo

Clínica Psiquiátrica Universitaria, Facultad de Medicina, Universidad de Chile.

Avenida La Paz 1003, Recoleta, Santiago, Chile.

Phone: +56 22978 - 8534

Email: mpidavanzo@hcuch.cl

Received: 3 July 2018

Accepted: 5 December 2018

Citation:

Pi Davanzo, M., Larraguibel Quiroz, M., Rojas-Andrade, R., Aldunate, C. (2018). Comparative study of adolescents with and without ADHD. (2018). Salud Mental, 47 (6), 287-296. doi: 10.17711/SM.0185-3325.2018.041

\section{(cc) (P) $(5)$}

\begin{abstract}
Introduction. Although an association between attention deficit hyperactivity disorder (ADHD) and personality disorders has been observed in adult population, no descriptions in Chilean adolescents have been reported. Objective. To explore personality profiles in Chilean adolescent patients diagnosed with ADHD. Method. Non-experimental, comparative design, convenience sample with 61 adolescent patients (13-19 years old) diagnosed with ADHD who completed the Millon Adolescent Clinical Inventory (MACI) questionnaire. Results compared parameters for the Chilean adolescent population and patients in the study. Attending psychiatrists completed a medical history file (comorbidities, pharmacological treatment and factors associated with mental health). Multivariate statistics, cluster analyses, and means comparison analyses were performed. This project was approved by the Ethics Committee of the University of Chile. Results. The personality profile of female adolescent patients with ADHD resembles that of the general female population, while the profile of the male patients is similar to that of the patient's parameter group. Cluster analysis identified two personality sub-profiles: $25 \%$ of the subjects belonged to cluster 1 , which was characterized by higher scores for different personality traits, expressed concerns, and clinical syndromes, compared with subjects from cluster 2 . There were no differences regarding gender, ADHD clinical presentation, use of medication, adverse childhood experiences (ACEs), type of school, grade retention, or, applicable only to the female group, comorbidities in belonging to cluster 1 . Only the presence of comorbidity in male subjects was associated with cluster 1 membership. Discussion and conclusion. Adolescent patients diagnosed with ADHD differed significantly in some personality traits when compared to Chilean parameters for the $\mathrm{MACl}$. Of the adolescents studied, $25 \%$ have maladaptive personality characteristics.
\end{abstract}

Keywords: Attention deficit hyperactivity disorder, personality, adolescents, comorbidity, MACI (Millon Adolescent Clinical Inventory).

\section{RESUMEN}

Introducción. Aún cuando en población adulta se ha observado una asociación entre el trastorno por déficit de atención con hiperactividad (TDAH) y el trastorno de personalidad, no se han reportado descripciones similares en población chilena. Objetivo. Explorar perfiles de personalidad en adolescentes chilenos consultantes diagnosticados con TDAH. Método. Diseño no experimental, comparativo y de muestra intencionada con 61 adolescentes consultantes diagnosticados con TDAH (13-19 años), que respondieron el inventario clínico de personalidad para adolescentes de Millon (MACl). Los resultados comparan los parámetros poblacionales de adolescentes no consultantes y consultantes chilenos con los resultados de los pacientes del estudio. Psiquiatras tratantes completaron las fichas de registro (comorbilidad, tratamiento farmacológico y determinantes asociados a salud mental). Se utilizaron estadísticos multivariados de aglomeración, análisis de clúster y análisis de diferencias de medias. Proyecto aprobado por el Comité de Ética de la Universidad de Chile. Resultados. El perfil de personalidad de las mujeres consultantes con TDAH se asemeja al grupo de adolescentes chilenas no consultantes y el de los hombres, al perfil de consultantes. El análisis de clúster identificó dos subperfiles de personalidad. El $25 \%$ de los sujetos perteneció al clúster 1, que se caracteriza por puntajes más altos para diferentes rasgos de personalidad, preocupaciones expresadas y síndromes clínicos, comparado con los sujetos pertenecientes al clúster 2. Sólo la presencia de comorbilidad en hombres se asoció a la pertenencia al clúster 1 , sin encontrarse diferencia por sexo, tipo de TDAH, uso de fármacos, experiencias adversas tempranas, tipo de colegio, repetición de grado escolar y diagnósticos comórbidos, sólo en el caso de las mujeres. Discusión y conclusión. Los adolescentes consultantes con TDAH se diferencian significativamente en algunos rasgos de personalidad al compararlos con los parámetros poblacionales chilenos para el MACI. El $25 \%$ de los adolescentes estudiados tienen características desadaptativas de personalidad.

Palabras clave: Trastorno de déficit de atención con hiperactividad, personalidad, adolescentes, comorbilidad, MACI (Inventario Clínico de Personalidad para Adolescentes de Millon). 


\section{INTRODUCTION}

Attention deficit hyperactivity disorder (ADHD) is a neurodevelopmental disorder that is highly prevalent in children and adolescents. The difficulties in the regulation of attention, hyperactivity, and impulsivity that characterize the disorder affect different areas of the development of children and adolescents who suffer from it, specially in learning and relationships with peers and family members (Barkley, 2006). ADHD is one of the main causes of consultation in child mental health. Chilean children and adolescents diagnosed with ADHD have high rates of use of services $(50.9 \%)$, compared to those with other disruptive disorders (27.6\%) and non-disruptive disorders (36.8\%) (de la Barra, Vicente, Saldivia, \& Melipillan, 2013).

Follow-up studies of children diagnosed with ADHD, compared with control groups, show that they have a higher-grade retention rate, participation on special educational needs programs, school suspensions, school expulsion, and lower academic performance. Fewer children with ADHD are able to enter university, and a lower percentage of them, graduate compared with the control group. Adults with ADHD suffer higher rates of job layoffs, change jobs more frequently, and have lower scores on performance evaluations. Certain activities of daily life, such as driving, are also affected, resulting in higher incidence of traffic fines, unsafe driving habits, and increased incidence of motor vehicle accidents (Barkley, 2002).

In relation to the association of ADHD with personality disorders (PDs), the life impact of ADHD was studied in a representative community sample of 34653 adults of the U.S. population. The prevalence of ADHD was $2.51 \%$ ( $n$ $=807$ ). They had a higher risk of presenting a diagnosis of any psychiatric disorder throughout their lives (94.98\%) than the general population (64.54\%), which included bipolar disorder (33.56\% ADHD - 6.23\% general population), generalized anxiety disorder $(25.99 \%-7.19 \%)$, post-traumatic stress disorder $(21.99 \%-6.02 \%)$, specific phobia $(35.75 \%$ - $14.61 \%)$ and personality disorder $(62.79 \%-20.46 \%)$ (narcissistic [25.16\% - 5.69\%], histrionic [10.74\% - 1.57\%], limit [33.69\% - 5.17\%], antisocial [18.66\% - 3.46\%], and schizotypal [22.42\% - 3.46\%]). In addition, ADHD throughout life was associated with a series of behaviors that imply lack of planning and poor inhibitory control. A greater number of adverse events was observed, less health, social support and greater perceived stress. Less than half of the individuals with ADHD had previously consulted a specialist and only a quarter had received medication (Bernardi et al., 2012).

A 10-year follow-up longitudinal study showed that ADHD onset during childhood poses risks to develop PDs later on in adulthood, such as borderline personality disorder, antisocial PD, avoidant PD and narcissistic PD (Miller et al., 2008). Subjects with persistent ADHD had a greater risk of developing antisocial PD and paranoid PD
(Miller et al., 2008). Some authors propose that the presence of ADHD could determine certain profiles of PDs, for example, patients with borderline PD and ADHD would have a more impulsive profile, while patients with borderline PD who did not suffer from ADHD would have more mood and anxiety disorders (Ferrer et al., 2010). Comorbid personality disorders may explain at least in part the psychosocial malfunction that some adults with ADHD have (Jacob et al., 2014).

In Chile, research on personality profiles of adolescent ADHD population is very limited, similar to the state of art in the rest of the world. The objective of this study is to explore the personality profiles of Chilean adolescent patients diagnosed with ADHD and compare them with the baseline population for the patient and non-patient groups. The aim is to highlight the importance of considering various elements in the diagnosis of adolescents with ADHD in order to develop and implement interventions appropriate to the specific needs of each patient.

\section{METHOD}

\section{Participants}

A convenience sampling was conducted in two psychiatric outpatient clincs in the Metropolitan Region of Chile. One center is the outpatient psychiatric unit of a university hospital and the other one is a private outpatient center. Adolescents having ADHD as the main diagnosis were invited to participate and were evaluated through clinical interviews conducted by two experienced child and adolescent psychiatrists who used DSM-5 criteria for the diagnosis of ADHD and comorbidities. Adolescents diagnosed with autism spectrum disorders, psychosis, cognitive disability, and those who did not know how to read and write were excluded from the selection.

\section{Instruments}

\section{MACI-A; Millon Adolescent Clinical Inventory}

MACI is an inventory that measures personality profiles in adolescents between 13 and 19 years of age. It was created by Theodore Millon in 1993. It has been validated in diverse populations showing adequate indexes of validity and reliability (Millon, 1987; 1993; Blumentritt \& VanVoorhis, 2004; Pinto \& Grillo, 2004; Aguirre, 2004). In Chile, this instrument was validated by Vinet (2006) and has been used in various studies in the country (Vinet \& Forns, 2005; Alarcón, Vinet, \& Salvo, 2005; Vinet \& Forns, 2006; Vinet \& Alarcón, 2009a; Vinet, Faúndez, \& Larraguibel, 2009; Vinet, Alarcon, \& Pérez-Luco, 2010). It is a self-administered written questionnaire, and its application takes approximately 30 
minutes. It consists of 160 items of true/false style answers that evaluates 31 scales, which are classified into: 12 personality prototypes, eight expressed concerns, and seven clinical syndromes. Prototype personality scales measure psychological functioning styles that emerge through development and stabilize in adolescence (Vinet, Barrera-Herrera, \& Salinas-Oñate, 2014). The expressed scales concerns measure feelings and attitudes about specific issues that worry adolescents. The scales of clinical syndromes measure the predisposition to present probable mental disorders during adolescence (Vinet et al., 2014). The present research considered the exploration of specific profiles that evaluate the psychological functioning of each adolescent and that include prototypes of personality, expressed concern, and clinical syndromes, in the same way that it has been used in other studies carried out in Chile (Vinet \& Forns, 2005; Alarcón, Vinet, \& Salvo, 2005; Vinet \& Forns, 2006; Vinet \& Alarcón, 2009b; Vinet et al., 2009; Vinet et al., 2010).

Determinants associated with mental health, comorbid disorders, and use of pharmacological treatment were recorded. This registration form was specially constructed for this research and includes the data of patient's identification, type of school, grade retention, type of presentation of ADHD, comorbidities, adverse childhood experiences (ACEs), and use of psychotropic drugs. The determinants associated with mental health were obtained according to the international literature, among which are the early adverse experiences (Felitti et al., 1998; Ramiro, Madrid, \& Brown, 2010; Finkelhor, Shattuck, Turner, \& Hamby, 2013; Pi, 2014), socioeconomic status (measured indirectly through the type of educational establishment), gender (Costa, Terracciano, \& McCrae, 2001; Klonsky, Jane, Turkheimer, \& Oltmanns, 2002; Biederman, Faraone, Monuteaux, Bober, \& Cadogen, 2004; Rucklidge, 2010; Weisberg, deYoung, \& Hirsh, 2011; de Bolle et al., 2015), and grade retention (Cohen, Crawford, Johnson, \& Kasen, 2005; Kent et al., 2011).

\section{Procedures}

The research team agreed on the diagnostic criteria for ADHD and comorbid disorders according to DSM-5 and the criteria for ACEs. Child and adolescents psychiatry residents and adolescents from the Clínica Psiquiátrica Universitaria (CPU) were invited to participate in the recruitment of patients. Subsequently, patients from a private psychiatric center where a member of the research team works were included in order to increase the sample size. The patients participating in the study signed assent (consent in the case of adults) and their parents' informed consent. The treating physicians applied the MACI questionnaire to adolescents who met the diagnostic criteria for the study and completed the registration form developed for this research. The later was carried out in conjunction with the principal investigator to verify that the criteria previously agreed upon were met.

\section{Design}

Empirical, non-experimental, quantitative, associative strategy research, using a cross-sectional comparative method and a design of natural groups according to the classification of Ato, López, and Benavente (2013). We sought to explore the association between the variables studied, in which the object of the exploration is the comparison at a given time of the sample groups, with the groups of patient and non-patient population of previous studies (Ato et al., 2013).

\section{Analysis}

To identify personality profiles of adolescents with ADHD, a sample $\mathrm{T}$ test was performed comparing the means obtained from our patients for each personality pattern to the means from each personality pattern from the reference parameters published in the Chilean validation study of standards for the MACI (Vinet, Fort, \& Santacana, 2008). Afterwards these profiles were compared to the patient and non-patient population referential data (Vinet et al., 2008). To identify personality sub-profiles, hierarchical conglomerate analyses were used to determine the optimal number of clusters to be found. We then performed Mann-Whitney U test to compare the difference of distributions for ordinal variables and $T$ test of two independent samples to compare the means of the two groups for quantitative variables. Finally, Biplot JH analysis was carried out, which allows the visual analysis of the matrix structure of the data, facilitating its interpreta-

Table 1

Frequency of variables of clinical presentation type of $A D H D$, grade retention, presence of comorbidity, presence of ACEs and use of medication for the total sample, women and men

\begin{tabular}{|c|c|c|c|c|c|c|}
\hline \multirow[b]{2}{*}{ Variable } & \multicolumn{2}{|c|}{ Total } & \multicolumn{2}{|c|}{ Female } & \multicolumn{2}{|c|}{ Male } \\
\hline & $n$ & $\%$ & $n$ & $\%$ & $n$ & $\%$ \\
\hline \multicolumn{7}{|c|}{$\begin{array}{l}\text { ADHD clinical } \\
\text { presentation }\end{array}$} \\
\hline Inatentive & 32 & $52 \%$ & 18 & $58 \%$ & 14 & $46.6 \%$ \\
\hline Hyp/imp & 3 & $5 \%$ & 1 & $3 \%$ & 2 & $6.6 \%$ \\
\hline Combined & 26 & $43 \%$ & 12 & $39 \%$ & 14 & $46.6 \%$ \\
\hline \multicolumn{7}{|c|}{ Grade retention } \\
\hline No & 47 & $77 \%$ & 25 & $81 \%$ & 22 & $73 \%$ \\
\hline Yes & 14 & $23 \%$ & 6 & $19 \%$ & 8 & $27 \%$ \\
\hline \multicolumn{7}{|c|}{ Comorbidities } \\
\hline No & 26 & $43 \%$ & 9 & $29 \%$ & 17 & $57 \%$ \\
\hline Yes & 35 & $57 \%$ & 22 & $71 \%$ & 13 & $43 \%$ \\
\hline \multicolumn{7}{|c|}{ Presence of ACEs } \\
\hline No & 21 & $34 \%$ & 10 & $32 \%$ & 11 & $37 \%$ \\
\hline Yes & 40 & $66 \%$ & 21 & $68 \%$ & 19 & $63 \%$ \\
\hline \multicolumn{7}{|l|}{ Medication } \\
\hline No & 28 & $46 \%$ & 14 & $45 \%$ & 14 & $47 \%$ \\
\hline Yes & 33 & $54 \%$ & 17 & $55 \%$ & 16 & $53 \%$ \\
\hline
\end{tabular}


Table 2

Comparison of means of MACl's personality patterns with patient and non-patient reference populations in the women's sample

\begin{tabular}{|c|c|c|c|c|c|}
\hline & & \multicolumn{2}{|c|}{$\begin{array}{c}\text { Difference with } \\
\text { non-patient population }\end{array}$} & \multicolumn{2}{|c|}{$\begin{array}{c}\text { Difference with } \\
\text { patient population }\end{array}$} \\
\hline & & Dif & $t$ & Dif & $t$ \\
\hline \multicolumn{6}{|c|}{ Personality Pattern } \\
\hline 1 & Introversive & 4.13 & $2.22^{*}$ & -9.25 & $-4.97^{* * *}$ \\
\hline $2 \mathrm{~A}$ & Inhibited & 3.52 & 1.78 & -9.75 & $-4.93^{\star \star *}$ \\
\hline $2 \mathrm{~B}$ & Doleful & .39 & .24 & -15.78 & $-9.74^{* * *}$ \\
\hline 3 & Submissive & -1.65 & -1.19 & 1.27 & $.92^{\star \star *}$ \\
\hline 4 & Dramatizing & -3.37 & -2.05 & 5.56 & $3.38^{* * *}$ \\
\hline 5 & Egotistic & -6.16 & $-4.02^{\star \star \star}$ & 1.63 & $1.06^{\star * *}$ \\
\hline $6 \mathrm{~A}$ & Unruly & 2.58 & 1.95 & -6.37 & -4.81 \\
\hline $6 \mathrm{~B}$ & Forceful & 2.42 & 2.01 & -4.21 & -3.50 \\
\hline 7 & Conforming & -4.66 & $-3.00^{*}$ & 7.12 & $4.58^{*}$ \\
\hline $8 \mathrm{~A}$ & Oppositional & 2.85 & 1.95 & -12.68 & $-8.66^{\star * *}$ \\
\hline $8 \mathrm{~B}$ & Self-demeaning & 4.65 & 2.03 & -15.88 & $-6.94^{\star \star \star}$ \\
\hline 9 & Borderline tendency & 2.63 & 2.15 & -9.02 & $-7.37^{\star * *}$ \\
\hline \multicolumn{6}{|c|}{ Expressed Concerns } \\
\hline A & Identity diffusion & 2.79 & 2.01 & -7.35 & $-5.30^{* * *}$ \\
\hline $\mathrm{B}$ & Self-devaluation & 4.61 & 1.86 & -15.40 & $-6.20^{\star \star *}$ \\
\hline $\mathrm{C}$ & Body disapproval & 3.12 & 1.76 & -3.67 & $-2.07^{* * *}$ \\
\hline $\mathrm{D}$ & Sexual discomfort & 1.14 & 1.24 & 4.23 & $4.57^{*}$ \\
\hline$E$ & Peer insecurity & .78 & 0.70 & -4.77 & $-4.33^{\star * *}$ \\
\hline $\mathrm{F}$ & Social insensitivity & -.22 & -.15 & -.19 & $-.13^{\star * *}$ \\
\hline G & Family discord & 2.25 & $2.25^{\star}$ & -5.30 & $-5.29^{*}$ \\
\hline $\mathrm{H}$ & Childhood abuse & .13 & .16 & -8.09 & $-10.14^{* * *}$ \\
\hline \multicolumn{6}{|c|}{ Clinical Syndromes } \\
\hline AA & Eating dysfunctios & 4.42 & $2.23^{*}$ & -4.67 & $-2.36^{\star * *}$ \\
\hline BB & Substance abuse proneness & 2.46 & $2.27^{*}$ & -7.50 & -6.90 \\
\hline $\mathrm{CC}$ & Delinquent predisposition & .10 & .09 & .53 & $.50^{\star * *}$ \\
\hline DD & Impulsive propensity & 1.41 & 1.38 & -4.01 & -3.91 \\
\hline EE & Anxious feelings & .20 & .17 & .68 & $.58^{\star * *}$ \\
\hline FF & Depressive affect & 2.90 & 1.63 & -11.53 & $-6.47^{* * *}$ \\
\hline GG & Suicidal tendency & 1.12 & .92 & -11.39 & $-9.36^{* * *}$ \\
\hline
\end{tabular}

Note: Dif $=$ differences between the observed value and the reference value; $t=\mathrm{t}$ student's statistics; ${ }^{* \star *} p<.001$, ${ }^{* *} p<.01,{ }^{*} p<.05$.

tion (Gabriel, 1971). To analyze if there were any differences in the cluster membership depending on the type of clinical presentation of ADHD, comorbidity, pharmacological treatment, and determinants associated with mental health (ACEs, type of school and grade retention), a chi square test was used. The variables grade retention, comorbid diagnosis, ACEs, and pharmacological treatment were considered as dichotomous variables (presence/absence). The SPSS 23 and STATA 12 programs were used to perform the analyses described. This study has the approval of the ethics committee of the Clinical Hospital of the University of Chile.

\section{RESULTS}

\section{Characterization of the sample}

In total, 61 adolescents were surveyed (50.8\% women), between 13 and 19 years of age (mean age 15.9 years, $S D=$
2.061 ). A total of $52 \%$ of the sample had a predominantly inattentive presentation of ADHD and $43 \%$ had a combined presentation (Table 1). When dividing the sample by gender, $58 \%$ of the female sample had a predominantly inattentive presentation of ADHD and 39\% had a combined presentation. In the men sample, $46.6 \%$ had a predominantly inattentive presentation, $46.6 \%$ a combined presentation, and $6.6 \%$ a predominantly hyperactive/impulsive presentation. Most of adolescents did not present a history of grade retention (77\%) (Table 1).

Regarding the presence of comorbidity, 35 adolescents (57\%) had at least one comorbid diagnosis, the most frequent being the presence of one comorbidity. In women, the most frequent were anxiety disorder (29\%), depressive disorder, and learning disorder (13\%). In men, the most frequent comorbid disorder was anxiety disorder (13\%).

Of the total sample and, disregarding gender 40 adolescents $(66 \%)$ had a previous history of having suffered at least one $\mathrm{ACE}$, being the most frequent to present only 
Table 3

Comparison of means of MACl's personality patterns with patient and non-patient reference population in the men's sample

\begin{tabular}{|c|c|c|c|c|c|}
\hline & & \multicolumn{2}{|c|}{$\begin{array}{c}\text { Difference with } \\
\text { non-patient population }\end{array}$} & \multicolumn{2}{|c|}{$\begin{array}{c}\text { Difference with } \\
\text { patient population }\end{array}$} \\
\hline & & Dif & $t$ & Dif & $t$ \\
\hline \multicolumn{6}{|c|}{ Personality Pattern } \\
\hline 1 & Introversive & 4.47 & $2.23^{*}$ & -2.42 & -1.21 \\
\hline $2 \mathrm{~A}$ & Inhibited & 3.47 & 1.75 & -3.87 & -1.98 \\
\hline $2 B$ & Doleful & 5.58 & $2.79^{*}$ & -5.00 & $-2.54^{*}$ \\
\hline 3 & Submissive & -1.49 & -.92 & 1.04 & .65 \\
\hline 4 & Dramatizing & -2.19 & -1.24 & .74 & .43 \\
\hline 5 & Egotistic & -4.23 & $-2.71^{*}$ & .50 & .33 \\
\hline $6 \mathrm{~A}$ & Unruly & 2.86 & 1.43 & -8.03 & $-4.07^{* * *}$ \\
\hline $6 \mathrm{~B}$ & Forceful & 3.96 & 1.96 & -1.62 & -.82 \\
\hline 7 & Conforming & -5.79 & $-2.87^{*}$ & 3.90 & 1.97 \\
\hline $8 \mathrm{~A}$ & Oppositional & 7.11 & $2.87^{*}$ & -4.09 & -1.68 \\
\hline $8 B$ & Self-demeaning & 8.79 & $3.02^{*}$ & -5.17 & -1.81 \\
\hline 9 & Borderline tendency & 6.00 & $3.13^{* * *}$ & -2.14 & -1.14 \\
\hline \multicolumn{6}{|c|}{ Expressed Concerns } \\
\hline A & Identity diffusion & 5.32 & $3.35^{* * *}$ & -2.33 & -1.49 \\
\hline $\mathrm{B}$ & Self-devaluation & 8.43 & $3.13^{* * *}$ & -5.20 & -1.96 \\
\hline $\mathrm{C}$ & Body disapproval & 3.95 & $2.58^{*}$ & .52 & .34 \\
\hline $\mathrm{D}$ & Sexual discomfort & -.82 & -.69 & 2.85 & $2.43^{*}$ \\
\hline$E$ & Peer insecurity & -.12 & -.11 & -1.91 & -1.84 \\
\hline $\mathrm{F}$ & Social insensitivity & -.72 & -.42 & -2.94 & -1.74 \\
\hline $\mathrm{G}$ & Family discord & 5.24 & $3.69^{* * *}$ & -.25 & -.18 \\
\hline $\mathrm{H}$ & Childhood abuse & 1.51 & 1.63 & -3.52 & $-3.85^{\star * *}$ \\
\hline \multicolumn{6}{|c|}{ Clinical Syndromes } \\
\hline AA & Eating dysfunctios & 5.07 & $2.86^{*}$ & .95 & .54 \\
\hline BB & Substance abuse proneness & 5.76 & $2.52^{*}$ & -6.02 & $-2.68^{*}$ \\
\hline $\mathrm{CC}$ & Delinquent predisposition & -.47 & -.44 & -5.07 & $-4.78^{* * *}$ \\
\hline DD & Impulsive propensity & 3.20 & 1.81 & -2.39 & -1.38 \\
\hline EE & Anxious feelings & .45 & .50 & 3.19 & $3.63^{* * *}$ \\
\hline $\mathrm{FF}$ & Depressive affect & 6.18 & $3.33^{* * *}$ & -2.01 & -1.10 \\
\hline GG & Suicidal tendency & 3.45 & $2.51^{*}$ & -4.41 & $-3.26^{* * *}$ \\
\hline
\end{tabular}

one of them. In the group of women, the ACEs included: living with a family member suffering from a mental disorder $(39 \%)$, divorce or separation of the parents $(32 \%)$, abandonment by the father (16\%), intra-family violence $(13 \%)$, and alcohol abuse by a relative $(10 \%)$. In the group of men, living with a relative who suffers from mental disorder $(20 \%)$, abandonment of the father $(17 \%)$, divorce or separation from the parents $(13 \%)$, intra-family violence, and physical abuse (10\%). Of the total sample, $54 \%$ was under pharmacological treatment, and for both sexes the most frequently used drug was methylphenidate $(76 \%$ and $75 \%$, respectively).

\section{Personality profiles of adolescents with ADHD}

To explore the personality profiles of the adolescents with ADHD, the scores obtained from the sample were compared with those of the reference population. Because MACI standards for Chilean population are differentiated according to gender, the statistical analyses conducted in this study for groups of men and women were considered separately.

\section{Females}

The sub-sample of women with ADHD behaved similarly to the group of non-patient women when responding to the MACI questionnaire as shown in Table 2. When compared with the non-patient population from the Chilean parameters, only six $(22 \%)$ of the 27 scales showed significant differences. The greatest differences were found in the scales 5 - egotistic - $(t[30]=-4.02 p=<.05)$ and 7 - conforming - $(t[30]=-3.00 p=<.05)$, where the studied group showed lower scores, and BB- substance abuse proneness - $(t[30]=$ $2.27 p=<.05$ ), where they showed higher scores. It should be noted that the egotistic and conforming scales are counter-theoretical scales used in the study of the validation of the instrument in the Chilean population, so that low scores on these scales are associated with mental health problems. 
Table 4

Configuration of clusters for female subjects according to MACl's Personality Patterns

\begin{tabular}{|c|c|c|c|c|c|c|c|}
\hline & \multicolumn{2}{|c|}{ Cluster $1(n=8)$} & \multicolumn{2}{|c|}{ Cluster $2(n=23)$} & \multirow{2}{*}{$\begin{array}{l}\text { U Mann- } \\
\text { Whitney }\end{array}$} & \multirow[b]{2}{*}{ Z } & \multirow{2}{*}{$\begin{array}{c}\text { Asymptotic } \\
\text { sig. (bilateral) }\end{array}$} \\
\hline & Mean & $S D$ & Mean & $S D$ & & & \\
\hline \multicolumn{8}{|l|}{ Personality Pattern } \\
\hline PB1 Introversive & 33.38 & 10.914 & 20.78 & 8.107 & 29.5 & -2.825 & .005 \\
\hline PB2A Inhibited & 37.88 & 7.453 & 18.26 & 6.614 & 5 & -3.933 & .000 \\
\hline PB2B Doleful & 23.25 & 5.365 & 5.52 & 4.133 & 0 & -4.161 & .000 \\
\hline PB3 Submissive & 55.00 & 8.848 & 52.74 & 7.43 & 77 & -.678 & .498 \\
\hline PB4 Dramatizing & 25.88 & 7.68 & 40.13 & 6.384 & 16 & -3.439 & .001 \\
\hline PB5 Egotistic & 19.75 & 7.146 & 31.48 & 6.781 & 22.5 & -3.142 & .002 \\
\hline PB6A Unruly & 23.13 & 6.686 & 24.91 & 7.687 & 82.5 & -.43 & .667 \\
\hline PB6B Forceful & 11.13 & 9.342 & 8.83 & 5.67 & 81 & -.498 & .619 \\
\hline PB7 Conforming & 43.88 & 8.167 & 49.17 & 8.553 & 60.5 & -1.425 & .154 \\
\hline PB8A Opositional & 25.38 & 8.262 & 15.13 & 6.363 & 28 & -2.896 & .004 \\
\hline PB8B Self-demeaning & 35.75 & 9.677 & 15.13 & 8.756 & 11 & -3.66 & .000 \\
\hline PB9 Borderline Tenden. & 19.38 & 5.423 & 10.35 & 5.662 & 21.5 & -3.2 & .001 \\
\hline \multicolumn{8}{|l|}{ Expressed Concerns } \\
\hline PBA Identity diffusion & 21.63 & 6.391 & 12.17 & 6.651 & 28 & -2.895 & .004 \\
\hline PBB Self-devaluation & 39.5 & 7.309 & 16.74 & 10.19 & 3 & -4.024 & .000 \\
\hline PBC Body disapproval & 21.75 & 5.825 & 10.83 & 9.466 & 34 & -2.626 & .009 \\
\hline PBD Sexual discomfort & 35.5 & 3.423 & 36.65 & 5.678 & 71.5 & -.931 & .352 \\
\hline PBE Peer insecurity & 15.63 & 7.386 & 6.61 & 3.474 & 19.5 & -3.287 & .001 \\
\hline PBF Social insensitivity & 16.5 & 8.229 & 23.22 & 7.045 & 40.5 & -2.337 & .019 \\
\hline PBG Family discord & 17.25 & 6.042 & 15 & 5.427 & 73.5 & -.837 & .403 \\
\hline PBH Childhood abuse & 10.88 & 3.482 & 3.83 & 3.114 & 12.5 & -3.613 & .000 \\
\hline \multicolumn{8}{|l|}{ Clinical Syndromes } \\
\hline PBAA Eating dysfunct. & 25.75 & 5.497 & 14.74 & 11.096 & 45.5 & -2.102 & .036 \\
\hline PBBB Substance abuse P. & 10.25 & 5.726 & 9.78 & 6.274 & 85.5 & -.295 & .768 \\
\hline PBCC delinquent pred. & 13.13 & 5.463 & 20.39 & 4.822 & 30 & -2.807 & .005 \\
\hline PBDD Impulsive prop. & 13.25 & 5.23 & 14.35 & 5.944 & 84.5 & -.34 & .733 \\
\hline PBEE Anxious feelings & 37.63 & 6.823 & 35.61 & 6.5 & 76.5 & -.701 & .483 \\
\hline PBFF Depressive affect & 31.5 & 5.372 & 13.52 & 6.141 & 5 & -3.93 & .000 \\
\hline PBGG Suicidal tendency & 15.87 & 6.081 & 3.35 & 2.917 & 2.5 & -4.064 & .000 \\
\hline
\end{tabular}

When comparing the group of women diagnosed with ADHD with the reference group of the patient population from the Chilean parameters, differences appeared in 23 $(85 \%)$ of the 27 scales. The greatest differences were found in scales $2 \mathrm{~b}$ - doleful - $(t[30]=-9.74 p=<.05), \mathrm{H}$ - childhood abuse $-(t[30]=-10.14 p=<.05)$ and GG - suicidal tendency $-(t[30]=-9.36 p=<.05)$, where lower scores are exhibited.

\section{Males}

The sample of male adolescents responding to the MACI questionnaire behaved similarly to the group of the patients, as shown in Table 3. When comparing male patients with ADHD with the reference non-patient population, they showed significant differences in 15 scales $(56 \%)$. The greatest differences were found in the scales A - identity diffusion $-(t[30]=3.35 p=<.05), \mathrm{G}$ - family discord $-(t[30]=3.69$ $p=<.05)$ and $\mathrm{FF}$ - depressive affect $-(t[30]=3.33 p=<$ $.05)$, where men with ADHD had higher scores than non-patient men. When comparing male adolescents with ADHD with the patient population, they showed significant differ- ences in eight scales $(30 \%)$. The greatest differences were found in the scales $6 \mathrm{~A}-$ unruly $-(t[30]=-4.07 p=<.05)$, $\mathrm{H}$ - childhood abuse - $(t[30]=-3.85 p=<.05)$, and CC - delinquent predisposition $-(t[30]=-4.78 p=<.05)$, where they obtain significantly lower scores.

\section{Personality sub-profiles of adolescent consultants with ADHD}

To describe personality sub-profiles within the group studied, the research team performed a hierarchical cluster analysis, which determined that the optimal number of clusters for the sample of adolescents with ADHD was two. A cluster of eight adolescents was configured for the female and male samples (cluster 1). The adolescents belonging to this cluster had higher scores on most of the MACI scales compared to cluster 2 subjects ( 23 women and 22 men) (Tables 4 and 5).

For both male and female subjects, the results of the MACI analysis in adolescents belonging to cluster 1 were found closer to the behavior of the scores of the patient population of the Chilean reference sample. In contrast, the results 
Table 5

Configuration of clusters for male subjects according to MACl's Personality Patterns

\begin{tabular}{|c|c|c|c|c|c|c|c|}
\hline & \multicolumn{2}{|c|}{ Cluster $1(n=8)$} & \multicolumn{2}{|c|}{ Cluster $2(n=22)$} & \multirow{2}{*}{$\begin{array}{l}\text { U de Mann- } \\
\text { Whitney }\end{array}$} & \multirow[b]{2}{*}{$Z$} & \multirow{2}{*}{$\begin{array}{c}\text { Asymptotic } \\
\text { sig. (bilateral) }\end{array}$} \\
\hline & Mean & $S D$ & Mean & $S D$ & & & \\
\hline \multicolumn{8}{|l|}{ Personality Pattern } \\
\hline PB1 Introversive & 36.38 & 10.211 & 21.41 & 8.33 & 18.5 & -3.263 & .001 \\
\hline PB2A Inhibited & 31.63 & 11.55 & 16.05 & 7.175 & 5 & -3.289 & .001 \\
\hline PB2B Doleful & 26.63 & 10.155 & 8.95 & 6.608 & 0 & -3.458 & .001 \\
\hline PB3 Submissive & 41.5 & 12.364 & 49.09 & 6.458 & 77 & -1.647 & .100 \\
\hline PB4 Dramatizing & 34.25 & 13.885 & 41.55 & 7.062 & 16 & -1.456 & .145 \\
\hline PB5 Egotistic & 30.75 & 12.859 & 36.05 & 6.153 & 22.5 & -.966 & .334 \\
\hline PB6A Unruly & 41.63 & 12.637 & 25.5 & 6.375 & 82.5 & -2.934 & .003 \\
\hline PB6B Forceful & 26.63 & 12.705 & 8.36 & 4.624 & 81 & -3.579 & .000 \\
\hline PB7 Conforming & 31.75 & 8.812 & 50.14 & 6.923 & 60.5 & -3.873 & .000 \\
\hline PB8A Opositional & 41.88 & 10.077 & 16.55 & 6.412 & 28 & -4.015 & .000 \\
\hline PB8B Self-Demeaning & 39.5 & 12.604 & 14.18 & 10.852 & 11 & -3.474 & .001 \\
\hline PB9 Borderline Tenden. & 27.13 & 11.606 & 10.45 & 5.422 & 21.5 & -3.859 & .000 \\
\hline \multicolumn{8}{|l|}{ Expressed Concerns } \\
\hline PBA Identity Diffusion & 28 & 3.338 & 12.55 & 5.853 & 28 & -3.991 & .000 \\
\hline PBB Self-Devaluation & 39.38 & 12.059 & 14.55 & 8.98 & 3 & -3.849 & .000 \\
\hline PBC Body Disapproval & 17 & 6.845 & 5.73 & 6.798 & 34 & -3.174 & .002 \\
\hline PBD Sexual Discomfort & 25 & 4.66 & 31.5 & 6.3 & 71.5 & -2.679 & .007 \\
\hline PBE Peer Insecurity & 10.75 & 7.592 & 7.18 & 4.817 & 19.5 & -1.133 & .257 \\
\hline PBF Social Insensitivity & 35.13 & 14.126 & 24.32 & 4.765 & 40.5 & -1.888 & .059 \\
\hline PBG Family Discord & 26.5 & 7.54 & 15.09 & 5.309 & 73.5 & -3.432 & .001 \\
\hline PBH Childhood Abuse & 11.25 & 5.701 & 3.14 & 2.55 & 12.5 & -3.638 & .000 \\
\hline \multicolumn{8}{|l|}{ Clinical Syndromes } \\
\hline PBAA Eating Dysfunct. & 20.38 & 8.815 & 6.68 & 7.22 & 45.5 & -3.455 & .001 \\
\hline PBBB Substance Abuse P. & 28.75 & 16.508 & 11.86 & 6.763 & 85.5 & -2.892 & .004 \\
\hline PBCC Delinquent Pred. & 24.38 & 10.197 & 22.23 & 3.504 & 30 & -.636 & .525 \\
\hline PBDD Impulsive Prop. & 26.5 & 13.32 & 15.05 & 5.753 & 84.5 & -2.632 & .008 \\
\hline PBEE Anxious Feelings & 30 & 5.707 & 32.05 & 4.593 & 76.5 & -1.013 & .311 \\
\hline PBFF Depressive Affect & 28.13 & 10.412 & 12.59 & 6.269 & 5 & -3.267 & .001 \\
\hline PBGG Suicidal Tendency & 15 & 8.751 & 4 & 4.353 & 2.5 & -3.229 & .001 \\
\hline
\end{tabular}

of the MACI analysis of adolescents belonging to cluster 2 were closer to the behavior of the scores of the non-patient population for the Chilean reference sample. Through the Biplot analysis, a visual analysis of the structure of the clusters was obtained for each sample (females and males), and the results are shown below in Figures 1 and 2.

We used Chi-Square tests in order to analyze the independence of the variables studied (type of clinical presentation of ADHD, type of school attended, grade retention, comorbid diagnoses, ACEs, and use of medication) in relation to belonging to any of the clusters. It was only found that in the group of men, the presence of comorbidity was associated with cluster 1 membership $\left(\chi^{2}[1, N=30]=4.455\right.$ $p<.05)$. No differences were found for the other variables.

\section{DISCUSSION AND CONCLUSION}

This research provides a new approach to describe personality traits in Chilean adolescents diagnosed with ADHD through the MACI questionnaire. The MACI questionnaire was simple and quick to apply, and provided valuable infor- mation, not only for personality characteristics, but also for situations that require more advanced attention (expressed concerns) and for indicators of possible comorbid clinical syndromes. Despite being a small convenience sampling, adolescents with ADHD are significantly differentiated for some personality traits measured through the MACI questionnaire, when compared with the general population parameters. The personality profile for the group of women with ADHD resembles the non-patient reference group; on the other hand, the personality profile for the men's group resembles that of the patient reference group. Based on these results, it can be stated that the group of female adolescent patients with ADHD included in this study had a more adaptive personality profile than the group of male subjects, which could lead to a lower risk of presenting personality disorder in the adulthood. On the other hand, special attention should be paid to the male patient population with ADHD to evaluate the need for preventive interventions in order to avoid the development of some type of personality disorder.

Follow-up studies of children with ADHD show that, compared with the general population, these children are 


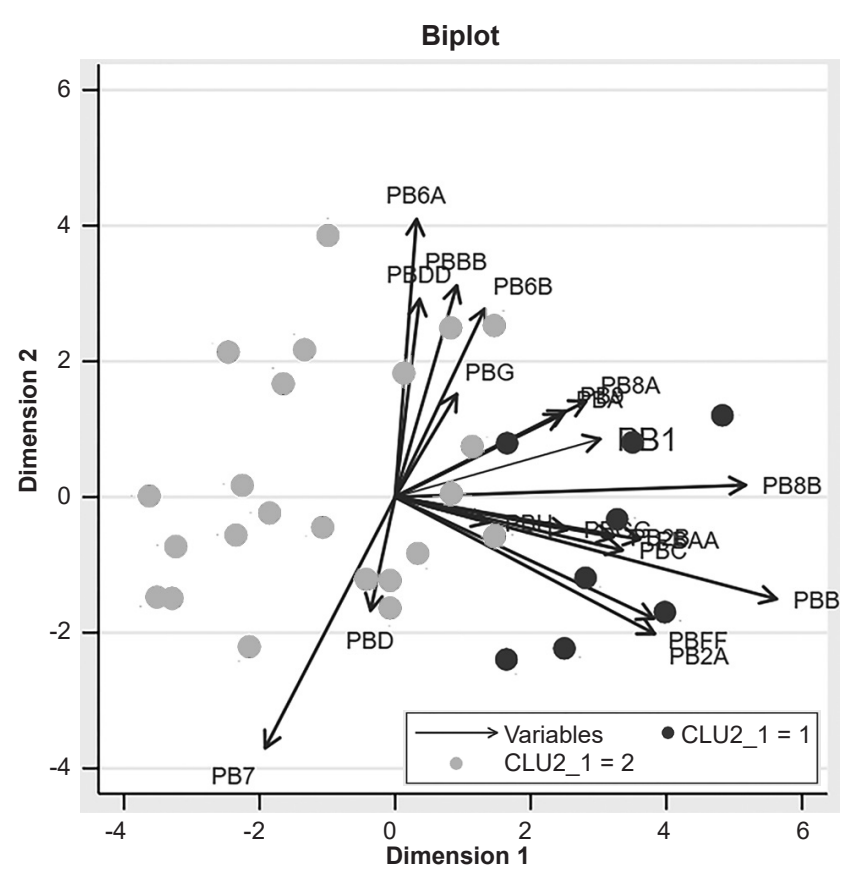

Figure 1. Biplot analysis for the female sub-sample based on the MACI'S personality patterns scales.

at an increased risk for poorer functioning and to suffer future psychopathology (Barkley, 2002; 2006; Biederman et al., 2006), including personality disorders (Miller et al., 2008; Matthies \& Philipsen, 2016). However, to our knowledge there are no studies that identify which children with ADHD are more likely to present a maladaptive personality functioning, which difficults the comparison of the results from this study with other research studies. There could be variables not studied here like the severity or persistence of the symptoms that could explain these maladaptive traits.

The cluster analysis and Biplot analysis applied to the sample detected two groups of personality sub-profiles in the adolescent patients with ADHD. Approximately $25 \%$ of the sample, for both men and women subjects, belongs to cluster 1 (women $n=8,25.8 \%$ - men $n=8,26.7 \%$ ). Cluster 1 was characterized by higher scores on most scales in the MACI questionnaire, i.e., adolescents belonging to this cluster have a sub-profile pattern of a more maladaptive personality than the ones belonging in cluster 2 . Based on these results, one could postulate that $25 \%$ of adolescents, both male and female presenting ADHD (belonging to cluster 1) may be at an increased risk of developing a personality with maladaptive traits, hindering the subject's lifestyle. Also, the presence of these traits could be predisposing factors for the development of future psychopathology requiring further assessment to evaluate the need for more specialized interventions.

Belonging to cluster 1 or 2 is not associated with the type of clinical presentation of ADHD, use of medication, adverse childhood experiences (ACEs), grade retention, or

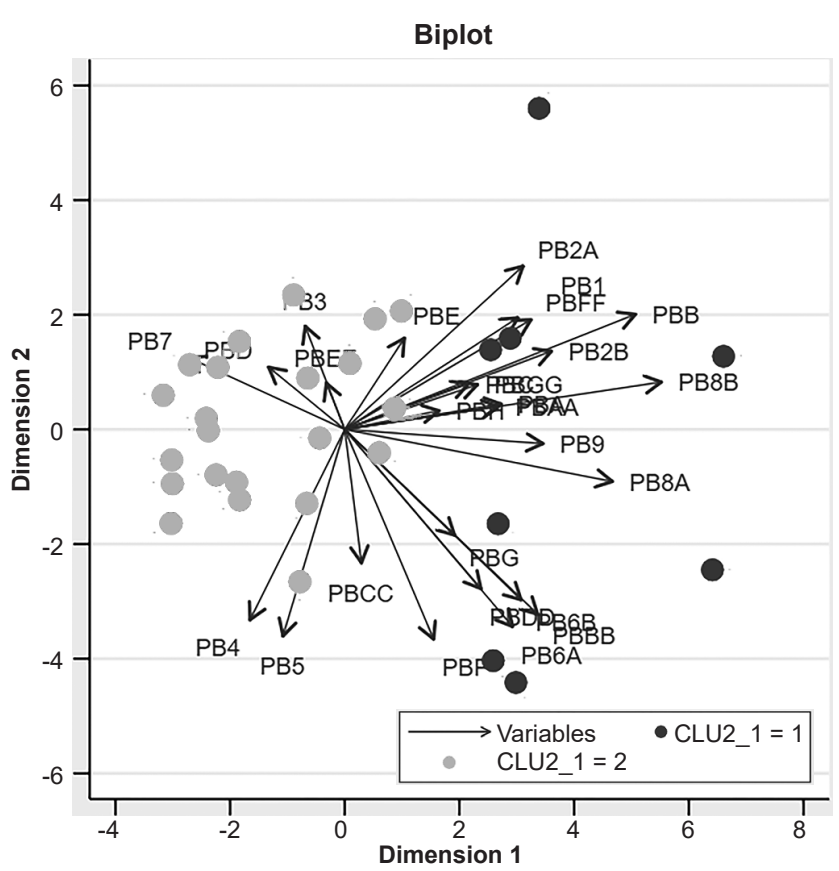

Figure 2. Biplot analysis for the male sub-sample based on the MACl'S personality patterns scales.

type of school. Only the comorbidity variable in men, but not for the women, was associated with cluster 1 membership. Comorbidity is frequent in children, adolescents and adults, with ADHD, and it is likely that the presence of this trait in adolescents with ADHD impacts the natural history and prognosis of individuals, favoring the development of maladaptive personality traits. The fact that only the comorbidity variable was associated with cluster 1 membership in male adolescent with ADHD and not in females may be due to the fact that most of the women in this study had a comorbidity $(71 \%)$, whereas in men it was less than half (43\%), which makes comparative analysis difficult for the group of female subjects. It is possible that variables not included in this study mediate belonging to a certain type of cluster, among which could be found the severity and age of onset of ADHD symptoms, characteristics of parenting, family functioning, neurocognitive functioning, self-esteem, social competence, and genetic markers, among others (Distel et al., 2011; Gómez \& Corr, 2014; Matthies \& Philipsen, 2016). Such variables could be included in subsequent studies and thus favor the detection of risk groups for the development of personality disorders in patients with ADHD.

Given these results and the importance of preventive interventions in the populations at risk, this research supports the suggestion to clinicians that considers the clinical characteristics of personality in the evaluation of adolescent patients with ADHD, since there would be a subgroup with maladaptive features that probably would require a meticulous detection of the factors that could be favoring 
the development of psychopathology. The Millon Adolescent Clinical Inventory (MACI-A) can be a useful tool in the early detection of maladaptive personality traits in adolescents with ADHD, which probably worsen the level of functioning of the individual. This study offers a tool for the evaluation and development of intervention strategies for adolescents affected by ADHD.

\section{Limitations}

The present study has several limitations that influence the interpretation of the results. The sample is not random or representative of the population and the sample size is small, which prevents the generalization of the results. Future research should include larger samples. In addition, the adolescents studied are patients, so there could be a subgroup of individuals who present severe and dysfunctional symptoms and who do not represent the population of adolescents with ADHD. Adolescents with hyperactive/ impulsive ADHD are underrepresented (5\% of the sample) and $57 \%$ have comorbidity, which could influence the results described. Although ADHD is highly comorbid, for future research it could be possible to compare groups of adolescents with ADHD with and without comorbidity and in this way assess whether ADHD is in itself predisposing the development of maladaptive personality traits, their comorbidities or both.

Because ADHD is a highly prevalent disorder in the child and adolescent population and is associated comorbidly with personality disorders in adulthood, it is important to consider that the approximately $25 \%$ of Chilean adolescents with ADHD present in this study, have important personality maladaptive features that could affect future functioning.

\section{Funding}

None.

\section{Conflicts of interests}

The authors declare they have no conflict of interests.

\section{REFERENCES}

Aguirre, G. Ll. (Ed.). (2004). MACI Inventario Clínico para Adolescentes de Millón. Manual. Madrid: TEA.

Alarcón, P., Vinet, E., \& Salvo, S. (2005). Estilos de Personalidad y Desadaptación social durante la adolescencia. Psykhe, 14(1), 3-16.

Ato, A., López, J., \& Benavente, A. (2013). Un Sistema de clasificación de los diseños de investigación en psicología. Anales de Psicología, 29(3), 1038-1059

Barkley, R. A. (2002). Major life activity and health outcomes associated with attention-deficit/hyperactivity disorder. The Journal of Clinical Psychiatry, 63(12), $10-15$.

Barkley, R. A. (2006). "The Nature of ADHD”, In R. Barkley. Attention Deficit Hyperactivity Disorder. A Handbook for Diagnosis and Treatment. New York: The Guilford Press.

de la Barra, F. E., Vicente, B., Saldivia, S., \& Melipillan, R. (2013). Epidemiology of ADHD in Chilean children and adolescents. ADHD Attention Deficit and Hy- peractivity Disorders, 5(1), 1-8. doi: 10.1007/s12402-012-0090-6

Bernardi, S., Faraone, S. V., Cortese, S., Kerridge, B. T., Pallanti, S., Wang, S., \& Blanco, C. (2012). The lifetime impact of attention deficit hyperactivity disorder: results from the National Epidemiologic Survey on Alcohol and Related Conditions (NESARC). Psychological Medicine, 42(4), 875-887. doi: 10.1017/ S003329171100153X

Biederman, J., Monuteaux, M. C., Mick, E., Spencer, T., Wilens, T. E., Silva, J. M., ... $\&$ Faraone, S. V. (2006). Young adult outcome of attention deficit hyperactivity disorder: a controlled 10-year follow-up study. Psychological Medicine, 36(2), 167-179. doi: 10.1017/S0033291705006410

Biederman, J., Faraone, S. V., Monuteaux, M. C., Bober, M., \& Cadogen, E. (2004). Gender effects on attention-deficit/hyperactivity disorder in adults, revisited. $B i$ ological Psychiatry, 55(7), 692-700. doi: 10.1016/j.biopsych.2003.12.003

Blumentritt, T. \& VanVoorhis, C. (2004). The Millon Adolescent Clinical Inventory: Is it valid and reliable for Mexican American youth? Journal of Personality Assessment, 83(1), 64-74. doi: 10.1207/s15327752jpa8301_06

de Bolle, M., De Fruyt, F., McCrae, R. R., Löckenhoff, C. E., Costa, P. T., Aguilar-Vafaie, M. E., ... \& Avdeyeva, T. (2015). The Emergence of Sex Differences in Personality Traits in Early Adolescence: A Cross-Sectional, Cross-Cultural Study. Journal of Personality and Social Psychology, 108(1), 171-185. doi: 10.1037/a0038497

Cohen, P., Crawford, T. N., Johnson, J. G., \& Kasen, S. (2005). The children in the community study of developmental course of personality disorder. Journal of Personality Disorders, 19(5), 466-486. doi: 10.1521/pedi.2005.19.5.466

Costa, P. T., Terracciano, A., \& McCrae, R. R. (2001). Gender differences in personality traits across cultures: robust and surprising findings. Journal of Personality and Social Psychology, 81(2), 322-331.

Distel, M. A., Carlier, A., Middeldorp, C. M., Derom, C. A., Lubke, G. H., \& Boomsma, D. I. (2011). Borderline personality traits and adult attention-deficit hyperactivity disorder symptoms: a genetic analysis of comorbidity. American Journal of Medical Genetics. Part B, Neuropsychiatric Genetics: The Official Publication of the International Society of Psychiatric Genetics, 156(7), 817825. doi: 10.1002/ajmg.b.31226

Ferrer, M., Andión, O., Matalí, J., Valero, S., Navarro, J. A., Ramos-Quiroga, J. A., ... \& Casas, M. (2010). Comorbid attention-deficit/hyperactivity disorder in borderline patients defines an impulsive subtype of borderline personality disorder. Journal of Personality Disorders, 24(6), 812-822. doi: 10.1521/ pedi.2010.24.6.812

Felitti, V., Anda, R., Nordenberg, D., Williamson, D., Spitz, A. M., Edwards, V., \& Marks, J. S. (1998). Relationship of childhood abuse and household dysfunction to many of the leading causes of death in adults. The Adverse Childhood Experiences (ACE) Study. American Journal of Preventive Medicine, 14(4), 245-258.

Finkelhor, D., Shattuck, A., Turner, H., \& Hamby, S. (2013). Improving the adverse childhood experiences study scale. JAMA Pediatrics, 167(1), 70-75. doi: 10.1001/jamapediatrics.2013.420

Gabriel, K. R. (1971). The biplot graphic display of matrices with application to principal component analysis. Biometrika, 58(3), 453-467. doi: 10.1093/biomet $/ 58.3 .453$

Gómez, R. \& Corr., P. J. (2014). ADHD and personality: A meta-analytic review. Clinical Psychology Review, 34(5), 376-88. doi: 10.1016/j.cpr.2014.05.002

Jacob, C. P., Gross-Lesch, S., Reichert, S., Geissler, J., Jans, T., Kittel-Schneider, S., \& Lesch, K.-P. (2014). Sex- and Subtype-Related Differences of Personality Disorders (Axis II) and Personality Traits in Persistent ADHD. Journal of Attention Disorders, 20(12), 1056-1065. doi: 10.1177/1087054714521293

Kent, K. M., Pelham, W. E., Molina, B. S. G., Sibley, M. H., Waschbusch, D. A., Yu, J., ... \& Karch, K. M. (2011). The Academic Experience of Male High School Students with ADHD. Journal of Abnormal Child Psychology, 39(3), 451-462. doi: 10.1007/s10802-010-9472-4

Klonsky, E. D., Jane, J. S., Turkheimer, E., \& Oltmanns, T. F. (2002). Gender Role and Personality Disorders. Journal of Personality Disorders, 16(5), 464-476.

Matthies, S. \& Philipsen, A. (2016). Comorbidity of Personality Disorders and Adult Attention Deficit Hyperactivity Disorder (ADHD)-Review of Recent Findings. Current Psychiatry Reports, 18(4), 33. doi: 10.1007/s11920-016-0675-4

Miller, C. J., Flory, J. D., Miller, S. R., Harty, S. C., Newcorn, J. H., \& Halperin, J. M. (2008). Childhood attention-deficit/hyperactivity disorder and the emergence of 
personality disorders in adolescence: a prospective follow-up study. The Journal of Clinical Psychiatry, 69(9), 1477-1484.

Millon, T. (1993). The Millon Adolescent Personality Inventory and the Millon Adolescent Clinical Inventory. Journal of Counseling \& Development, 71(5), 570-574.

Millon, T. (1987). Millon Clinical Multiaxial Inventory: II (MCMI-II) Manual. Minneapolis: National Computer Systems.

Pi, M. (2014). Experiencias Tempranas de Estrés Psicosocial en la Niñez y Adolescencia y la Asociación con Salud General y Salud Mental. Revista Gaceta de Psiquiatría Universitaria, 10(4), 410-418.

Pinto, M. \& Grilo, C. M. (2004). Reliability, diagnostic efficiency, and validity of the Millon adolescent clinical inventory: examination of selected scales in psychiatrically hospitalized adolescents. Behaviour Research and Therapy, 42(12), 1505-1519. doi: 10.1016/j.brat.2003.10.006

Ramiro, L., Madrid, B., \& Brown, D. (2010). Adverse childhood experiences (ACE) and health-risk behaviors among adults in a developing country setting. Child Abuse \& Neglect, 34(11), 842-855. doi: 10.1016/j.chiabu.2010.02.012

Rucklidge, J. J. (2010). Gender differences in attention-deficit/hyperactivity disorder. The Psychiatric Clinics of North America, 33(2), 357-373. doi: 10.1016/j. psc.2010.01.006

Vinet, E., Barrera-Herrera, A., \& Salinas-Oñate, N. (2014). El MACI en Chile: Desarrollo culturalmente pertinente de un test para adolescentes. Revista Iberoamericana de Diagnóstico y Evaluación-e Avaliação Psicológica, 1(37), 123-145.

Vinet, E., Alarcón, P., \& Pérez-Luco, R. (2010). Detección y descripción de rasgos psicopáticos en adolescentes utilizando el MACI. Universitas Psychologica, 10(3), 705-719.

Vinet, E., Faúndez, X., \& Larraguibel, M. (2009). Adolescentes con trastorno por consumo de sustancias: una caracterización a través de las normas chilenas del MACI. Revista médica de Chile, 137(4), 466-474.

Vinet, E. \& Alarcón, P. (2009a). Caracterización de personalidad de mujeres adolescentes infractoras de ley: un estudio comparativo. Paideia, 19(43), 143-152.

Vinet, E. \& Alarcón, P. (2009b). El Inventario Clínico para Adolescentes de Millon (MACI) en la evaluación de adolescentes chilenos. Psykhe, 12(1), 39-55.

Vinet, E., Forns, M, \& Santacana, M. (2008). Normas Chilenas para el MACI: Una Integración de Criterios Categoriales y Dimensionales. Terapia Psicológica, 26(2), 151-163.

Vinet, E. (2006). Definición de las Escalas MACI y estadísticos descriptivos de referencia. Proyecto DIDUFRO 120612. México: Universidad de la Frontera.

Vinet, E. \& Forns, M. (2006). El inventario clínico para adolescentes de Millon (MACI) y su capacidad para discriminar entre población general y clínica. Psykhe, 15(2), 69-80.

Vinet, E. \& Forns, M. (2005). Adolescentes no consultants en riesgo: una evaluación a través del MACI. Anuario de Psicología, 36(1), 83-97.

Weisberg, Y. J., deYoung, C. G., \& Hirsh, J. B. (2011). Gender Differences in Personality across the Ten Aspects of the Big Five. Frontiers in Psychology, 2, 178. doi: 10.3389/fpsyg.2011.00178 